\title{
Nigerian Politicians and the Leadership Question in Emeka Nwabueze's A Parliament of Vultures and Alex Asigbo's The Reign of Paschal Amusu
}

\author{
Emmanuel O. Iroh \\ http://dx.doi./org/10.4314/ujah.v20i3.13
}

\begin{abstract}
African countries have consistently been involved in civil unrest, political instability, threats of secession, selection instead of election as well as rigging of elections, sit tight leaders and many more malaise. Despite the fact that Africa is blessed with enough human, material and natural resources, yet most of these resources have been grossly mismanaged or fretted away by her leaders who have refused to rise above board. The aim of the research is to portray the efforts of our dramatists in exposing the machinations of our leaders in their quest to retain power and acquire wealth to the detriment of the masses. The objectives of the study is to expose some these devices and enlighten the public on the schemes of their leaders and politicians who pretend to be serving the public while in the real sense are enriching themselves while impoverishing the masses as well as to expose the different ways in which these heinous crime against the people are perpetrated. The research adopted the qualitative methodology and a context analysis approach of two drama texts of Emeka Nwabueze and Alex Asigbo. The findings show that politicians adopt many tactics to fulfill their selfish and inordinate ambitions to the detriment of the nation which this paper sets to interrogate. The paper therefore concludes that drama has continued to be a potent tool in exposing societal ills. The study recommends conscientization and reawaking of national consciousness of both the leaders and the general public.
\end{abstract}


Iroh: Nigerian Politicians and the Leadership Question in Emeka Nwabueze's A Parliament of Vultures and Alex Asigbo's The Reign of Paschal Amusu

Keywords: Leaders, Politicians, Dramatists, Masses.

\section{Introduction}

Theatre no doubt has remained an important means of communication and indeed an invaluable channel for the exhibition of craft of the playwright. Oscar Brocket maintains that since the inception of theatre in ancient Greek to the present day, the theatre and especially playwrights have used their skills as a major gauge in mirroring and conscientizing the society. Dramatists, both of old and new generations, have always portrayed societal malady in their writing to either create awareness or deter their leaders from continuing in their unpatriotic acts. Unfortunately, the more these writers write, the more these leaders and their cohort device new means to subvert the will of the people.

African countries have consistently been involved in civil unrest, threats of secession, political instability; sit tight leaders, despotism, election rigging and instability, lack of transparency in governance, graft, self acquisition of state funds and many other vices, have consistently retarded the continent, thus stalling economic, political, social as well as human and material development. Despite the fact that Africa is blessed with natural and mineral resources, yet most of these resources have been grossly mismanaged, with the result that African citizens are daily being drowned in the Atlantic Ocean or starved to death in the Sahara desert while trying to cross the ocean or desert in search of greener pastures.

African leaders can be broadly categorized into two main groups namely, the transformational and the transactional. Transformational and transactional are adjectives. Transformation, according to the Encarta Dictionary transformation is associated with change. It is "Complete change: usually into something with 
an improved appearance or usefulness. Transforming is "the act or process of transforming somebody or something"(www. Encarta dictionary.com).Transaction on the other hand is "an instance of doing business of some kind; act of negotiating something or carrying out a business deal" (www. Encarta dictionary.com). Specifically put, transformational leaders are leaders who assume leadership positions with the aim of making impact, improving on the situation they met, laying foundations that will improve the lots of the people. Such leaders offer selfless service for the betterment of the people and their society. On the other hand, transactional leaders assume leadership positions with a mind set of transacting business. Such leaders are likened to a withdrawal of funds from a bank account. They are self centered, inconsiderate and insensitive to the feelings of the people and their society. All they care about is what they get from the position they are occupying without giving or contributing to improve the situation they met. In the local parlance, they are usually referred to as garbage in garbage out leaders. Unfortunately, most African leaders belong to this group. They see themselves as people in a transactional position.

It is to clearly elucidate the recklessness and lackadaisical attitudes of our leaders that this work has chosen Nwabueze's $A$ Parliament of Vultures and Asigbo's The Reign of Paschal Amusu as case studies to showcase the efforts of our dramatists, as watch dogs of the society in the depiction our leaders' indifferent attitudes towards nation building. The choice is deliberate.

\section{Theoretical Conception}

This work is hinged on the formalist concept of script analysis. Fundamentally, the formalist approach grew out of the need to be more objective and scientific than other approaches especially the symbolist approach. It was championed by Russian born Victor 
Shklovsky who led the society for the study of poetic language (OPPYAZ). The formalists advocated for the appreciation of a written text based on its content rather than external influences. Accordingly, the formalistic theory entails extricating the meaning of any work of art from the work itself. That is, the meaning of any work of art is locked within the work itself and does not depend on any external influence (s) as all works of arts must explain itself. The approach is likened to the arts for art's sake advocacy championed by Walter Peter and Oscar Wilde. According to, Peter and Wilde insist that "a work of art should be detailed by its own formula of creativity rather than extensive factors" (blog.bcu.ac.uk). The formalist concept is referred to "as a critical theory that analyze, interpret and evaluate the inherent features of a text...reducing the importance of a text's historical, biological and cultural context" (www.Wikipedia.com) the above assertions are in line with the approach adopted for this work which is the content analysis approach. Thus, the formalist approach is to $\mathrm{x}$ ray the inherent qualities and meanings in the selected texts as used by the playwrights.

\section{A Parliament of Vultures: Synopsis}

A Parliament of Vultures mirrors the lives of Nigerian parliamentarians. The parliament is one the tripod on which democratic governments worldwide stands. Therefore, parliamentarians are supposed to show exemplary leadership as watchdog on the executive and judiciary arms of government to curtail executive irresponsibility, lawlessness and recklessness. The play therefore exposes the machinations of our political leaders as represented by the legislator/ parliamentarians to enrich themselves as well as retain power to their selfish benefit. 
It is set in a parliamentary house, made up of representatives from different parts of the state. Like is the practice in most parliaments, A Parliament of Vultures is made up of both majority and minority members and clearly exposes the intrigues of the majority, made up self centered and greedy members who maneuver, oppress, and suppress the minority members who genuinely want the progress of the assembly and who have better suggestions and alternatives and plans on how to run an efficient and seamless administration to better the country.

However, the majority, leveraging on their numerical strength, shares political positions among themselves, awards contract to their cronies who most of the time are not qualified and appropriates budgetary allocations to projects that they have vested interest or to their cronies. To fully appropriate the common wealth of the people to themselves without further opposition, the majority members plot and order the arrest and detention of the minority members which led to students protest and unrest, culminating in the sacking and burning of the legislative house and freeing the detained legislatures.

\section{Nigerian Politicians and the Leadership Question: Portrayal of politics and leadership in $A$ Parliament of Vultures}

Patriotism, self service and love for one's fatherland are some of the qualities or hallmark of a statesman. However, these qualities are far from some members in The Parliament of Vultures as portrayed by the author. Rather what we see is self aggrandizement, selfishness, greed and infighting among the parliamentarians, placement of mediocrity above excellence, financial recklessness and impropriety and legislative rascality and manipulations. 
Leadership should be a selfless and patriotic endeavour, but what we see in the parliament of vultures and indeed in most of our leaders is nothing to write home about. Even before they are inaugurated, plans of how to loot and enrich themselves must have been well orchestrated and hatched. These selfish tendencies of our leaders (legislators) who are elected to serve are severally portrayed by Nwabueze in The Parliament of Vultures. Madam Omeaku, a barely literate, hotel proprietor who has just been elected into office is preoccupied with what lucrative positions she will occupy in parliament to enable her loot the treasury instead of rendering service to the people.

Madam: $\quad$ To be an honourable member is not enough.

What matters is the position you get in parliament. That determines your financial security

Again, Mr Brown, another newly elected member of the parliament, in seeking Madam's support for a committee chairman, he is plotting to occupy, assures her of his cooperation and bounty reward she will get in return for her support.

Brown: That's why you have to support me in my quest for the chairmanship of the purchasing committee in the parliament. In a couple of months, you'll have enough refrigerators to give as present to your friends (10).

To achieve the above and many of their self serving machinations, the legislators on many occasions are preoccupied with legislative manipulations. These are evident in the use of voice votes of the majority to outwit the minority by tacitly upholding that "the minority must be heard and the majority must prevail" (53) thus shutting out the opposition and illegally removing the house 
secretary on trumped up charges and his replacement with an unqualified and semi literate member to extinguish oppositions and compromising quality.

The financial recklessness of the leaders as represented by the members of the parliament is evident portrayed through the way and manner approvals and appropriations were made in the parliament. Although there are many instances of these, two examples will suffice. For a parliamentary party and honouring of a church invitation, the speaker approves ten billion naira and two billion naira without recourse that such money would have been appropriated for either road construction or provision of health facility or to education to better the lives of the people.

Habamero: I take that the business of the parliament has been taken care of. It is clear that most of the members are in support of it ....

Madam: $\quad$ how much can we play around with? I mean the vote for the party

Habamero: judging from the importance of such business, I'd say about a hundred million

Parkers: (shouting) Christ Almighty

Madam: will that be enough? Aren't we going to invite our friends?

Parkers: $\quad$ Great heavens! This is criminal (67)

Even when the opposition has kicked against such financial recklessness of the house especially towards such frivolities as attending a church invitation, the majority in most cases overrules them and goes ahead to have their way. 
Otobo:

We should not encourage such invitations. I understand that a member of this parliament is involved in the activities of the church. We should not encourage people to send invitations to us as a body (68)

Instead of listening to the voice of reasoning, and being frugal, the speaker over rules the opposition and goes ahead to approve a whopping two billion for a private engagement for the house and self aggrandizement. This was done after lady honourable member, Madam Omeaku has reeled out the requirements of the members like appropriate dresses, hiring of special music group and even inconvenience allowance when the members are attending the church invitation.

Habamero: You have seen, honourable Otobo, that ten million naira will not be adequate to take care of this business. The bulk of the money will be disbursed through the payment of inconvenience allowances to members for attending the thanksgiving service. Extra expenses will be accrued through the making of appropriate dresses for members and hiring the music group. I therefore, approve the sum of two billion naira for the purpose. Approved!
All:
(except Parkers and Otobo) Approved!
Parkers: $\quad$ Excuse me Mr Chairman...
Habamero: Overruled Dr Parker
Parkers: Then count me out of it 
Otobo: $\quad$ Me too, I won't participate in that circus show either. (73)

What an approval from a parliament that is supposed to be frugal and selfless in their position as watchdog for the executive. This attitude is also replicated during the parliamentary appointment of board members as all useful suggestions by Parkers and Otobo for the appointment of qualified, credible and capable persons who would bring experience and quality to bear in the discharge of their responsibilities were compromised through the selection and appointment of incompetent, inexperienced and unqualified party faithful and their cronies.

Parkers: I Insist that we evaluate people on the basis of their curriculum vitae and their possible contribution to the development of their possible contribution to the development of this nation before appointing them. I have a list with me here and each of them has a descent resume which is open to the scrutiny of the members of the house. (75)

What follows afterwards is very disheartening as the above sincere and patriotic advice was jettisoned and the chairman's suggestion to the house on the kind of persons to be appointed for board positions was adopted despite the objections.

Habamero: We shouldn't appoint a person who as the proverb goes, will forget the person who pulled off its feathers during the raining season.

Parkers: Objections $\mathrm{Mr}$ Chairman. That position needs a man of integrity, a man who would place his technological knowhow at the 
disposal of the company. I have on my list for that position, Professor Dogon Turenchi, the design of the Faculty of Engineering at the University of Songhai. A man with untainted record, a man whose publications in the international journals have earned him international recognition and eminence, man of competence...(75)

However, the house rejected the above recommendation because he has neither contributed to their party nor chipped anything about the party in his publications. Thereafter, all board appointments from cement industry to vegetable oil and Radio and Television were all reserved for party faithful and their cronies. The most laughable are the appointment of Alhaji BarawoOleh and Chief Anu Mpama. Alhaji BarawoOleh was preferred to a Lawyer because he sells vegetable oil in Gelele market while Chief Anu Mpama though a pardoned party stalwart who was detained for embezzlement was the party Chairman's candidate. All the appointments made by the parliament threw caution to the winds.

\section{The Reign Paschal Amusu: Synopsis}

The play rightly captures the events that occurred in Nigeria after the unfortunate annulment of the 1993 general elections and the intrigues of a self seeking, power hungry cabal aimed at perpetuating themselves or their cronies in power. After a general election which was overwhelmingly won by Shiwo and acclaimed by the international observers as very transparent was annulled, tempers rose and tension was high, this led to the resignation of the military president who sets up an interim government populated by his nominees to conduct a fresh election. The supposed winner of 
the election flees and when he comes back to claim his mandate is thrown into jail where he dies in mysterious circumstances. Shasha overthrows the lame interim government and becomes despotic. He however slumps and dies. This led the formation of a transition military government to conduct election and hand over to civilians

To placate Shiwo and his region, Amusu is released from jail and selected as president in a highly doctored election with the understanding that he will do a single tenure and hand over power to Masi. However, Amusu having tasted power jettisons the agreement and runs for a second tenure, plans for a third tenure to the chagrin of Masi and his group. Instead of retracting when the tenure elongation failed, Amusu cleverly plots and hands over power to his nominee after a massively rigged election.

\section{Nigerian Politicians and the Leadership Question: Portrayal of Politics and Leadership in The Reign of Paschal Amusu}

The nature of African leaders are fully exposed by Amusu who concludes that majority of them are transactional leaders who came to power to steal, loot and cart away public properties. According to him:

Amusu:

All the infrastructures I left during my last reign have all degenerated... and to make matters worse, all these criminal rulers that came after me have looted the treasury of this nation to stupor (13).

In most instances and in almost all African States, there is hardly any patriotic leader in who thinks about his country first. All they scheme is for their benefit. They say one thing and mean another. Commissions are set up not for national interest but for political witch hunting of perceived enemies and rivalries. Sonny 
Amusu is lobbied to join Amusu's government. At his recommendation, a commission for financial crime is to be established, not to fight crime but for the persecution of Amusu's perceived political enemies and rivals.

Odibo:

... Sony Anita has agreed to put his wits at your disposal. Indeed, as an example of what he can do, he recommends the establishment of the Bureau for financial crimes investigation. According to him, it will be a potent weapon against perceived political opponent (15)

Continuing, Odibo explains that Sonny Anita has recommended Mallam Rilwanu Lulu to head the body which Amusu gladly accepts and immediately signs both for the establishment of the financial bureau as well as the appointment of lulu as the head of the commission

For the political leaders are obsessed with remaining in power that they forget that the primary objective of the position is service and state function. As Amusu's tenure is about to end, he reneges on the promise to hand over power back to Masi but instead plans for tenure extension or third term. This angers Masi who feels threatened that power may elude him and goes to confront Amusu.

Masi: What is this new agenda we hear you are espousing with Sonny Anita?

Amusu: New agenda? Oh, you mean our reform agenda?

Masi: Damn it sir. Stop trivializing things. No one is interested in your fake reform. We are 
talking of your plans to rail road the legislatures into approving a tenure elongation.

\section{Amusu: $\quad$ Oh that, no comment (18)}

Most political leaders' main preoccupation in Africa is the plotto remain in office for life or may be to die in office, instead of devoting more time to plan and execute developmental projects; greater part of their energy is wasted on political intrigues and scheming. After all attempts made to forestall Masi from contesting against Amusu, Amusu digs deep to unravel Masi's past deed in office and confronts him with the threat of exposing him. To this, Masi quickly withdraws, retraces his steps and backs down from the race. He is however cajoled to make his withdrawal public through a press broadcast which he did.

Masi: $\quad$ Your Excellency sir, having considered the merits and demerits of my contesting the presidency and in the overall interest of my country, I feel most obliged to withdraw from the presidential race (32)

But Amusu pretentiously answers him.

Amusu:

Hmm... A true patriot. Wo. Generations yet unborn will remember you for the sacrifice you made for the unity of this country (33)

Leaders in developed countries will do everything to avert crises. They will manage the situation well if it ever erupted but not so for African leaders' nay Nigerian leaders who instigate the crises through their actions and explore avenues to gain from it. This is because crises give them opportunities to loot the treasury. First Amusu directs Sonny Anita to send a presidential jet to 
Iroh: Nigerian Politicians and the Leadership Question in Emeka Nwabueze's A Parliament of Vultures and Alex Asigbo's The Reign of Paschal Amusu

Pitakwa to bring Wariboko for discussion without thinking of the cost and waste that will entail.

Amusu: Send the presidential jet to Pitakwa immediately. Arrange for their leader Esuene Wariboko brought here. We need to have a heart to heart with him

Sonny: At once my President

Amusu: $\quad$ Offer him anything as long as they step up their terrorism during the elections (23)

\section{Conclusion}

The work used two texts, Nwabueze's A Parliament Of Vultures and Asigbo's The Reign of Paschal Amusu to investigate the topic; Nigerian Politicians and the Leadership Question in Emeka Nwabueze's A Parliament Of Vultures and Alex Asigbo's The Reign of Paschal Amusu as paradigm to examine the efforts of our playwrights in exposing poor leadership attitudes of our politicians. The findings show that our political leaders lack self discipline and adopt many tactics to fulfill their selfish want to the detriment of the masses. The work successfully brought to fore the self centered attitudes of some of our leaders which has resulted in leadership and backwardness of most African states especially the most populated black nation, Nigeria. Dramatists like Femi Osofisan in A Restless Run Of A Locust, KelechiOgbonna in No More Stain, Barclays Ayakoroma in A Chance to Survive and of course, Emeka Nwabueze in A Parliament of Vultures and Alex Asigbo in The Reign of Paschal Amusu clearly expose the inordinate and evil machinations of Nigerian leaders after our independence to the present time.

Osofisan in 1969, seven years after Nigeria's independence, captured the evil machinations and maneuverings of 
our politicians to retain power. These leaders place acquisition of political power above all other considerations as they are willing to kill, maim, or even sacrifice their family to achieve their selfish interest. This is clearly captured by Sanda after Chief Kuti sent some thugs to attack and kill his political opponent in his quest to stop all perceived oppositions seen as stumbling block to his winning the election:

Sanda:

I would'nt call it a fight. It was a massacre. They caught us unaware and we were too few for them. (rubbing his hand) By god, I thought that last blow had knocked my head off (he begins to rearrange the furniture)

Similarly, Emmanuel Emasealu, in his introductory note on Barclays Ayokorama's play, "A Chance to Survive and Other Plays" exposes the selfishness of our leaders who will rather prefer to marry more wives and live in affluence even when their kingdom is on fire than to work for the overall benefit and betterment of their community. To them what matters is their comfort, political and economic power. Emasealu submits thus:

His Royal Highness (Dr) Kurokaki, the great Ibedaowei, the supposed custodian of tradition and protector of his subject, receives twenty million naira from an oil company as compensation for gas explosion. Karokaki, rather than do an equitable distribution of this amount among his subjects or spend the said amount judiciously for the benefit of his people, wastes the money in taking a seventh wife as well as "buying" an honourary doctorate degree.(10)

Perhaps, it is this failure of leadership in our clime that necessitatesthe call by StellaMarisOgbonna for a return to the 
traditional oath taking by our leaders and politicians to make them accountable to the people. In No More Stains, the people acknowledge the rot in their country which necessitated the call for the return of the traditional method(s) of oath taking where every aspirant is made to come to the village square to talk about his manifesto. This they do by standing on the Ekwu-igwe (Tripod cooking stand):

Atuma:

We as a people have suffered so much in the hands of our leaders. All the access roads to this village are bad and even pedestrian hardly find space to walk their way to Nkwo Ngwa Market...

Ekwe: we all were witnesses to the show of shame displayed by our representatives... may I call on the three aspirants to mount the Ekwu-igwe...

Marizu: $\quad$ As for my integrity, I am a child raised within the perimeters of tradition. I know the consequences of standing on this Ekwuigwe (Tripod cooking stand). If I am elected, I will not only be transparent, but will work with the people and for the people.

According to Ogbonna, is it to avert the above calamity and hold the representatives accountable that they must be subjected "to an efficacious oath of equitable service" (v) which renders quick judgment and reprimands offenders and recalcitrant leaders. This will propel leaders to self restrain and being committed to excellence. 
The work concludes that drama has continued to be a potent factor, a watchdog of the society and will continue to be used in exposing the ills in the society as well as for the reposition of the society.

\section{Emmanuel O. Iroh (PhD)}

Department of Theatre \& Film Studies

NnamdiAzikiwe University, Awka

irohemmaogbo@gmail.com

\section{Works Cited}

Asigbo Alex. The Reign of Paschal Amusu.Valid Publishing Company, Awka. 2008.

Brockett, Oscar G. History of the Theatre. Reinhart and Winston. USA. 2004.

Emasealu Emmanuel. Introduction on A Chance to Survive and

Other Plays. Kraft Books Ltd. Ibadan. 2011.

Microsoft Encarta Dictionary. Microsoft Corporation. 2009.

............Encyclopedia. Microsoft Corporation. 2009.

Nwabueze Emeka. A Parliament of Vultures. Abic Book \&Equip Ltd. Enugu. 2000.

OgbonnaStellaMarisKelechi. No more StainsValid publishing company, Awka. 2017.

Osofisan Femi. Restless Run of a Lucust.StrassPress, Ibadan. 1969.

Walter Peter and Oscar Wilde. Formalism: The Virtual Theorist. blogs.bcu.ac.uk Accessed 23/10/19.

Wikipedia. The Formalist Concept. www.wikipedia.com. 